\title{
Sustainability Accounting and Competitive Advantage of Quoted Companies in Nigeria
}

\author{
Ishola Rufus Akintoye \\ Professor of Accounting \& Strategic Financial Management \\ Department of Accounting, School of Management Sciences, Babcock University \\ Ilishan-remo, Nigeria \\ E-mail: irakintoye@yahoo.com
}

Oluwasikemi Janet Taiwo (Corresponding author)

PhD Candidate

Department of Accounting, School of Management Sciences, Babcock University

Ilishan-remo, Nigeria

E-mail: taiwooluwasikemi01@gmail.com

Babatunde Ayodeji Owolabi

Lecturer and PhD Candidate

Department of Accounting, School of Management Sciences, Babcock University

Ilishan-remo, Nigeria

E-mail: owolabiba@babcock.edu.ng

Received: May 20, 2020

doi:10.5296/ijafr.v10i2.17062
Accepted: June 11, 2020

Published: June 30, 2020

URL: https://doi.org/10.5296/ijafr.v10i2.17062

\begin{abstract}
This study examined the effect of sustainability accounting on competitive advantage of quoted companies in Nigeria. The study adopted ex-post facto research design with 167 listed firms as the population. 28 quoted firms were chosen with the use of purposive sampling.
\end{abstract}


Data from 2009 to 2018 were obtained from secondary sources. Content analysis was employed as a tool to analyze the disclosures in sustainability reports. Models were estimated using the Hausman test. The findings of the study shows that sustainability accounting measures have a significant joint effect on change in turnover and market share with Prob. (F-stat) of $0.03533<0.05$ and $0.0000<0.05$ respectively. Therefore, concludes that sustainability accounting has a significant effect on competitive advantage since practicing and accounting for sustainability will create reputational benefit for the companies.

Keywords: Change in turnover, Competitive advantage, Market share, Reputational benefits, Sustainability accounting

\section{Introduction}

Business organisations have a primary objective of profit-making, and at the same time, there should be strategies in place to ensure the achievement of its goals and existence in the long run. In today's competitive business world, organisations need to adopt policies to outperform their rivals. Competitive advantage is an essential factor in the maximisation of shareholders' wealth as a principal objective of business organisations (Wijayanto, Suhadak \& Nuzula, 2019). Survival of an organisation is paramount, especially with the various resulting destabilisation in micro and macroeconomic variables in the likes of increased unemployment level, reduced return on investment, and increased poverty level. In the global market, what is most important is not the size of companies but its reputation as firms can exert great powers and influence when they have products and services that are scarce and more valuable (Aswini, 2013). Likewise, the features of the market in which a firm operates are significant as it may turn out that none of the companies in that industry developed competitive advantage (Pawel, 2016). Competitive advantage is a multidimensional concept that has the possibility of been reflected at the firm, industry, and national level. It's an essential factor that can ensure the long term prosperity of a firm and nation (Vilani, 2017). As such, there is no competitive nation without competitive organisations.

Globally, the size of an organisation is not what is essential but some intangible qualities such as reputation and scarcity. Companies will be able to exert high power when they have features that are rare and valuable (Aswini, 2013). Business organisations need to pursue a competitive advantage that can surpass their business rivals as well as the industrial average. To achieve this, firms will have to figure out and understand how their strengths can supercede their weaknesses. The three (3) largest revenue-based manufacturing multinational companies such as the Volkswagen Group, Toyota group, and Apple as at the year 2017 have used various strategic management practices to achieved and sustained their competitive advantage over the years (Ismail, Rose, Abdullah \& Uli, 2010; Wikipedia, 2019). In this globalisation era, industries and companies compete with each other, and as such, Nigerian business organisations have much to earn from the strategic management processes.

The manufacturing sector in Nigeria is a relevant component of the economy as it is one of the most significant contributors to the economic growth of the nation. Its relevance includes its contribution to nominal Gross Domestic Product (GDP) estimated at $11.32 \%$ at the ending of quarter one of 2019 and 9.28\% at the end of quarter one of 2018 (National Bureau of 


\section{Ml Macrothink}

International Journal of Accounting and Financial Reporting

ISSN 2162-3082

2020, Vol. 10, No. 2

Statistics, 2019). According to Ismail, Rose, Abdullah and Uli (2010), competitive advantage is the prerequisite for successful performance. Likewise, the agricultural and services sectors are of great importance to Nigeria's economy, and their competitive advantages are to be enhanced. The factors that determine competitive advantage include level of diversification, merger and acquisition, organisational structure, operational efficiency, leadership style by management, conformity with environmentally, economically and socially responsible behaviours, human resource management and international expansion (Wijayanto, Suhadak \& Nuzula, 2019; Zhao, Meng, He \& Gu, 2019).

Relational dimension of a firm with its stakeholders is a factors that affect the competitive advantage of an organisation. This relational dimension is expressible through strategies like sustainability accounting/reporting. Sustainability accounting is an extension of the traditional financial reporting system directed towards providing credible information on the environmental, social and governance practices of firms to stakeholders. Traditionally, information published in the annual reports of companies were financial information which was usually insufficient for stakeholders decision making (Akintoye, Jayeoba, Ajibade, Olayinka \& Kwarbai, 2016). Since the mid-1990s, companies have increased information reported by providing non-financial information on their activities to their stakeholders (Kolk, 2004). Over time, sustainability accounting has been used by firms as a tool in achieving economic goals through the disclosures of its environmental, social and governance activities to enhance its sustainment (Persic, Jankovic \& Krivacic, 2017).

With sustainability accounting, companies will be able to disclose information that is extensive than internal communication to boost their reputations. Undertaking sustainability accounting can meet the needs of various stakeholders by reducing information asymmetry between the management of the firms and the stakeholders from which organisations can derive competitive advantage (Zhao et al., 2019). Some scholars opined that business organisations remain static after the achievement of some levels of success which may be due to the absence of the need to develop and maintain more enormous advantages (Pawel, 2016; Urbanowska-Sojkin, Banaszyk \& Witczak, 2007; Wang, Senaratne \& Rafiq, 2015). However, competitive advantage possesses relative features that depreciate with time, based on the dynamic changes in the environment. Thus, this study examined how sustainability accounting can serve as a tool for creating a competitive advantage in the corporate aspect of Nigeria. The research hypothesis is as follows:

Ho1: Sustainability accounting exerts no significant effect on changes in turnover of quoted companies in Nigeria.

Ho2: Sustainability accounting exerts no significant effect on the market share of quoted companies in Nigeria.

\section{Literature Review}

\subsection{Competitive Advantage}

Wijayanto, Suhadak and Nuzula (2019) opined that competitive advantage is a superior position achieved by a company as a result of its successful strategy and challenging to 
imitate. Vilani (2016) suggested that competitive advantage happens when quality of goods and services are improved with reduction in cost of production and enlargement of market share or profit. According to Al-najjar (2016), competitive advantage is the capability of a company to outshine within the active participation in the market while realising an adequate return. The dimensions through which competitive advantage was measured include cost, quality, differentiation, creativity and flexibility. Also, Sachitra (2015) defined competitive advantage as a specific way by which a firm uses its activities and resources to keep the firm distinct from its competitors.

Similarly, Aswini (2013) suggests that competitive advantage occurs when the product or services of a firm as perceived by its target market customers are better than that of its competitors. The difference between the net value created and compared to the costs of competitors shows the magnitude of the competitive advantage of a company. If the economic value derived is more than those of the rivals, the firm has a competitive advantage; if it is the same then the company has competitive parity; and when the economic value is lower, the company has a competitive disadvantage (Aswini (2013; Rothaermel, 2008). In the same vein, Smith (2014) opined that the extent to which firms in a particular region can compete with firms in other regions can be referred to as competitive advantage. Thus, a competitive advantage occurs when a superior position is attained with the use of a system of strategy.

The ideal situation that cause competitive advantage includes resource heterogeneity, ex-post limits to competition, ex-ante limits to competition and imperfect resource mobility. Competitive advantage is a significant factor that determines companies` performance and profitability. Thus, the indicators of competitive advantage include reputation/image, quality product/service, technological skills, distribution capability, industrialized capability, financial assets, customer service skills, innovation competency and cost position (Aswini, 2013). Competitive advantage involves implementing strategies that utilise the resources of an organisation, and such policies are to be valuable and make the company superior to its competitors (Wirda, 2019). The strategy should ensure enhancing company's performance with related low cost. A unique set of attributes developed by a firm can result in the firm outperforming its competitors. Thus, when the activities of a firm are more profitable than its competitors, it reveals its competitive advantage (Paweł, 2016).

\subsection{Measures of Competitive Advantage}

The measurement methods used by various experts in determining the altitude of competitive advantage include resource-based indicators and non-resource based indicators (Dickinson \& Sommers, 2012; Wijayanto, Suhadak \& Nuzula, 2019). The resource-based indicators are based on barrier to entrance such as: product differentiation, innovation, economies of scale and capital requirements. The non-resource indicators are built on market or industry, such as: power over customers, supplier and integrity tp retaliate to possible threats (Porter, 1985; Wijayanto, Suhadak \& Nuzula, 2019). Likewise, competitive advantage measurement can be based on past performance or potential competitive indicators. It includes productivity, market share, return on asset, product cost, net income, gross margin, unit cost ratio and 
financial performance (return on investment, sales growth and profit). Also, it includes non-financial performance (balanced scorecard, employees growth, benchmarking and customer satisfaction) (Farole, Guilherme \& Wagle, 2010; Kiel, Smith \& Ubbels, 2014; Kortelainen \& Karkkainen, 2011; Kozena \& Chladek. 2012; Rahman \& Ramli, 2014; Toit, Ortmann \& Ramroop, 2010; Wijayanto, Suhadak \& Nuzula, 2019). However, this study will measure competitive advantage with changes in turnover and market share (to be proxy with market capitalisation) to capture objectively, the competitive stand of an organisation beyond the short term. Changes in turnover is defined as current year sales minus previous year sales, while market share is defined as the market capitalisation of the quoted selected firms.

\subsection{Sustainability Accounting}

The limitation of corporate social responsibility (CSR) on ensuring accountability to the stakeholders led to sustainability accounting which provides information to stakeholders on its environmental, social and governance activities (Persic, Jankovic \& Krivacic, 2017). Sustainability accounting involves recording and disclosing non-financial information as a support to the conventional financial reporting system which influences the financial position and earnings of the firm. Sustainability accounting as an accounting system provides credible and relevant information to stakeholders on the social, economic and environmental activities of an organisation (Persic, Jankovic \& Krivacic, 2017). It has turn out to be a management tool for firms to grow sustainable and achieve economic goals.

According to Suprita (2018), sustainability accounting involves firms disclosing to stakeholders the non-financial information of their performance. Likewise, sustainability accounting involves recording and reporting the sustainability practices of firms to its stakeholders (Emeka-Nwokeji \& Osisioma, 2019). Also, Konstantinos and Dimitrios (2016) opined that sustainability accounting is the disclosure of an integral approach to sustainable issues which is driven by stakeholders ' pressure, legislative and ethical reasons. According to Whetman (2017), sustainability accounting is the practice that encompasses a company's value, governance model and its approach towards creating a sustainable global economy.

A complete form of accounting has become critical based on the societal changes; thus, sustainability accounting involves three (3) dimensions of social sustainability, governance sustainability and environmental sustainability. The social sustainability dimension relates to the collective system inside and outside the firm, which encompasses labour practices, human rights, product responsibility and society (Persic, Jankovic \& Krivacic, 2017). The labour aspect attends to worker and supplier-related features of the firm such as training and having the same opportunities. Also, human rights aspect attends to child labour, favoritism, oppression and policies in place to achieve them. The aspect of society involves thecooperation with communities, donations to the societies and fines for not been law compliant. Product responsibility is the final aspect which captures the level of satisfaction guest satisfaction with firm`s products and employee or customer`s loyalty (GRI, 2015).

The environmental sustainability dimension involves organizational practices in minimising the operational negative impacts on the ecosystem. Its subcategories include materials, effluents, energy, biodiversity, waste, emissions, compliance and environmental grievance 


\section{$\Lambda$ Macrothink}

International Journal of Accounting and Financial Reporting ISSN 2162-3082

mechanisms (Persic, Jankovic \& Krivacic, 2017). When an organisation is an environmental concern, it saves cost in the long run and improves the firm-stakeholder relationship. There are firms that are proactive in managing their wastes and pollutions among others. The measures include treatment of waste, reduction of pollution, reduction of $\mathrm{CO}_{2}$ emission, production of valuable goods, reuse of materials, conservation of energy and treatment of water (Taiwo \& Owolabi, 2019).

The corporate governance aspect ensures responsibility for and accountability of the social, economic and environmental sustainability of a firm through the board of directors (NSE, 2016). The main aim of governance dimension is to enhance the protection and proper management of stakeholders` interest. These goals are to aid accountability, fairness and transparency in firm`s practices. Its indicators include corporate governance formation and board composition, internal control mechanisms, and the role of board of directors in risk management and evaluation of other dimensions of sustainability practices (GRI, 2015; Ucheagwu, 2019).

\subsection{Global Reporting Initiatives (GRI) and Nigerian Stock Exchange (NSE) Sustainability} Framework

GRI sustainability framework presents the principles that guide the preparation and reporting of sustainability activities of organisations. The GRI guidelines serve as the manual for companies in implementing the reporting of sustainability regardless of the location, size of the firm and sector (Isa, 2014). The guideline of GRI is a global benchmark for reporting sustainability practices. The development of the GRI guidelines was through the involvement of multi-stakeholders globally which includes regulators and representative of government agencies. The purpose of the framework is to ensure that accurate, transparent and comparable information are made available in the sustainability report for stakeholder's decision (GRI, 2011).

Also, in Nigeria, sustainability reporting guideline of Nigerian Stock Exchange (NSE) got to its implementation stage in 2015. The guideline gives the principles to be followed by its listed firms in disclosing sustainability practices. The framework provides the indicators to be published by companies concerning their environmental, economic, governance and social activities to enhance the decision making of the various interested parties (NSE, 2016).

\section{Theoretical Framework}

\subsection{Signaling Theory}

Theory of signaling is propounded by Michael Spencer (1973). It is premised on the need to reduce information asymmetry between the organisation and their stakeholders by deliberately disclosing necessary information (Connelly, Certo, Ireland \& Reutzel, 2011). Thus, firms need to provide detailed and accurate information to the stakeholders. By voluntarily disclosing information, organisations can differentiate themselves from their peers as the better performing and responsible ones (Adekunle \& Asaolu, 2013). The theory expresses that voluntarily disclosing the information can enhance public loyalty, increased demand for the goods, services and shares of such organisations (Loh, Thomas \& Wang, 2017). Thereafter, 
these will result in a competitive advantage for such firms. Therefore, when firms account for and disclose their social, environmental and governance practices, it sends signals to the public informing them of the proactive strategies taken as an entity that is responsible, thus, creating reputational benefits and competitive advantages

\subsection{Empirical Review}

Uchehara (2019) expressed that CSR has significant positive effects on firm return on sales (ROS) and return on investment (ROI) by examining the effect of corporate social responsibility (CSR) in improving corporate competitiveness for firms in the consumer goods sector in Nigeria. The study used panel data obtained from 12 firms from 2015 to 2017. Two models representing Return on Investment and Return on Sales were developed and regressed on CSR investment variable. The study concludes that CSR is a veritable management strategy for enhancing corporate competitiveness of business in Nigeria.

Also, Wijayanto, Suhadak and Nuzula (2019) examined the impact of competitive advantage on financial performance and value of manufacturing firms in Indonesia. Competitive advantage was measured with the cost of sales, innovation ratio, market share, capital intensity, operating liability leverage, inventory turnover, receivable turnover and financial leverage. Financial performance was proxy with return on asset, return on equity and asset turnover. At the same time, the firm value was measured with Tobin's Q, market value of equity and market to book value ratio. It examined 30 manufacturing firms in Indonesia by analysing the data on the company's financial statements of the period from 2010 to 2016. Data were analysed using Generalised Structured Component Analysis (GSCA). The research work finds competitive advantage to exert a significant positive impact on financial performance and value of companies. Also, financial performance shows a significant positive impact on firm`s value. Thus, the study provide the proof that competitive advantage impact financial performance and value of firms.

Paweł (2016) analysed the interaction between Corporate Social Responsibility (CSR) activities and competitive advantages. The study discussed how firms embark on CSR activities and the benefits derived from such activities. Polpharma group company was used as the case study for the research. The study finds that there are several benefits that a firm can derived from CSR practices and can later results to competitive advantages. Analysing Polpharma group company indicates that there are positive results and beefits from CSR practices as there will be improvement in customer loyalty and enhancing of firms competitiveness.

Wirda and Rivai (2019) opined that entrepreneurial competency has a significant positive impact on performance of firms, entrepreneurial skill exerted significant positive impact on competitive advantage, competitive advantage has a significant positive impact on firm performance, and competitive advantage is the mediating effect of entrepreneurial competency and business performance. The findings were as a result of determining the influence of entrepreneurial competency on business performance with competitive advantage as a mediating variable. 213 business managers of the creative industry in the craft sector in West Sumatra-Indonesia were used as samples. Sampling area was employed as 
sampling technique and the sample was distributed according to the probable areas of the innovative industries of West Sumatra craft sector, including Sawah Lunto district, Tanah Datar, 50 Kota, Agam, Bukittinggi, Padang, Padang Panjang, and Pariaman. Questionnaires were used as the instrument for collecting data and analysed by Structural Equation Modeling (SEM) using AMOS software.

Aziz (2019) investigated the relationship that exists among managerial competencies , organisational capabilities and competitive advantage with the sample of 330 food processing SMEs in Malaysia. The relationship between capabilities and competitive advantage was tested with structural equation modelling using AMOS to examine the moderating role of managerial competencies. The study found a positive and significant relationship between organisational capabilities and competitive advantage. Also, the study found that managerial capability mediates the relationship between organisational capabilities and competitive advantage fully.

Zhao, Meng, He and Gu (2019) examined the impact of Corporate Social Responsibility on Competitive Advantage (CA) through largely ignored perspectives of organisation resources and capabilities. Dynamic capabilities and social capabilities were the mediating variables used for the study. The survey research design was adopted with 269 questionnaires distributed to 112 firms in China. The study showed that CSR exerted positive direct and indirect impact on CA with structure and relational dimensions of CA as mediating variables. The study concludes that firms can gain competitive advantage by combining external social measures, internal competitive resources and capabilities properly.

Ahmad, Tawfiq, Ayman and Sakher (2019) identified the effect of social responsibility dimensions in achieving competitive advantages at Jordanian supply chain companies. The methodology of the study was quantitative and qualitative. The population of the study consists of Jordanian supply chain companies. The data collected were analysed, and the study found corporate social responsibility does not affect the competitive advantage of Jordanian supply chain companies. The finding was due to factors like the number of employees, age of firm and firm's size. Likewise, the study found from the literature that ethical, economical, legal and philosophical are the significant aspects of social responsibility.

Yu, Kuo and Kao (2017) investigated the impact of Corporate Social Responsibility (CSR) disclosure on competitive advantage by applying signaling theory to determine how firm in China can use GSR disclosure can be used to improve the competitive advantage and image of firms. Sampled firms were selected among the firms in China that are CSR dedicated. 711 reports were obtained from 2008 to 2009 with exception of the reports of foreign companies and banking and insurance firms. Competitive advantage was proxy with intellectual capital and the early improvement of CSR practices were used to measure the impact of strategic CSR on competitiveness. The findings indicate that despite the difference in ownership patterns, CSR disclosure has no significant impact on competitive advantage. Thus, CSR disclosure is not sufficient in achieving and enhancing competitive advantage of firms. 


\section{Ml Macrothink}

International Journal of Accounting and Financial Reporting

ISSN 2162-3082

2020, Vol. 10, No. 2

However, the literature reviewed focus on corporate social responsibility (CSR) which is streamlined to the social aspect of sustainability and neglect the governance and environmental issues an organisation can engage in to improve its competitive position. Likewise, the primary source of data (questionnaire) has been used by most previous studies to measure competitive advantage. Thus, neglecting secondary sources that will be able to validate the hypothesis and evaluate the appropriateness of the model with the obtained data more objectively (Aziz \& Samad, 2016; Diab, 2014; Samad, Aziz, Jaidi \& Masoud, 2016; Zhao, Meng, He, \& Gu, 2019). Thus, to fill the gaps, the study considered sustainability accounting as a tool for creating competitive advantage for firms in Nigeria.

\section{Methodology}

Ex post facto research design was used for his study to ensure a post review of the firms' approach to sustainability practices in providing competitive advantage. The study considered 167 listed firms on the Nigerian Stock Exchange (NSE) as at 31st December 2018 as the population. A sample of 28 quoted companies was chosen purposively using the criteria below: the firm`s annual reports must be accessible from 2009 to 2018, and the firm should have available sustainability reports for the selected prtiod.

Data were obtained from accounts and sustainability reports published of the selected firms. Sustainability accounting was measured with the dimensions of environmental sustainability, governance sustainability, economic sustainability and social sustainability. In contrast, competitive advantage was measured with changes in turnover and market share (proxy with market capitalisation). Content analysis was employed as a tool to evaluate the content of sustainability reports of the selected firms as regards their sustainability performance. The compliance level of the selected firms were benchmarked against the sustainability guidelines of Global Reporting Initiative and Nigerian Stock Exchange. This method of analysis has been used in prior studies (Ching, Gerab \& Toste, 2017). The study is a static analysis, hence made use of the fixed effects and random-effects model. A choice between them was made using the Hausman test. The model specifications are as follows:

$$
\begin{array}{ll}
\log (\text { CTO })_{\text {it }}=\beta_{0}+\beta_{1} \text { SOSA }_{\text {it }}+\beta_{2} \text { EVSA }_{\text {it }}+\beta_{3} \text { GOSA }_{\text {it }}+\mu_{\text {it }} & \text { Model } 1 \\
\log (\text { MS })_{\text {it }}=\beta_{0}+\beta_{1} \text { SOSA }_{i t}+\beta_{2} \text { EVSA }_{i t}+\beta_{3} \text { GOSA }_{i t}+\mu_{\text {it }} & \text { Model } 2
\end{array}
$$

Where:

CTO represents Change in Turnover

MS represents Market Share

SOSA represents Social Sustainability Accounting

EVSA represents Environmental Sustainability Accounting

GOSA represents Governance Sustainability Accounting

$\mu$ represents Error Term

Change in Turnover $=$ current year sales minus previous year sales 
Market share $\mathrm{i}=$ the market capitalisation of the quoted selected firms.

\subsection{Data Analysis and Interpretation of Result}

Data on Competitive advantage (proxy with changes in turnover and market share) and sustainability accounting (proxy with social sustainability accounting, environmental sustainability accounting and governance sustainability accounting) were gathered from the year 2009 to 2018 of 28 sampled quoted companies. The results are discussed below:

\subsection{Correlation Result}

The association among the variables is revealed by the correlation matrix shown below:

Table 1. Correlation result

\begin{tabular}{llllll}
\hline & CTO & MS & SOSA & EVSA & GOSA \\
\hline CTO & 1 & & & & \\
\hline MS & 0.0891 & 1 & & & \\
\hline SOSA & 0.0073 & 0.5346 & 1 & 1 & \\
\hline EVSA & 0.0939 & 0.5357 & 0.7388 & 1 \\
\hline GOSA & 0.0318 & 0.4467 & 0.7102 & 0.8057 & 1 \\
\hline
\end{tabular}

Source: Author`s computation (2020)

The correlation result in Table 1 reveals that SOSA, EVSA and GOSA have a positive relationship with Change in Turnover (CTO) with the R-values of 0.0073, 0.0939 and 0.0318, respectively. Also, there exists a positive relationship with Market Share (MS) with the R-values of $0.5346,0.5357$ and 0.4467 , respectively. Thus, the correlation result shows that there's is positive interaction between sustainability accounting measures and competitive advantage measures of the sampled quoted companies for the period under study.

\subsection{Regression Result}

The results of the study are presented and discussed here. The data obtained were regressed by conducting Hausman test which was to choose the best option between fixed effect and random effect.

Hypothesis one: Sustainability accounting exerts no significant effect on changes in turnover of quoted companies in Nigeria.

In other to present an efficient result, both fixed and random effect models are estimated. The results are stated below:

Table 2. Summary of fixed effect and random effect result

\begin{tabular}{|c|c|c|c|c|c|c|c|c|}
\hline & Fixed Effec & & & & Random Ef & ect & & \\
\hline Variable & Coefficient & $\begin{array}{l}\text { Std. } \\
\text { Error }\end{array}$ & $\mathbf{t}$ & Prob. & Coefficient & $\begin{array}{l}\text { Std. } \\
\text { Error }\end{array}$ & $\mathbf{t}$ & Prob. \\
\hline $\mathbf{C}$ & 9.582766 & .3626965 & 26.42 & 0.000 & 9.400917 & .4368877 & 21.52 & 0.000 \\
\hline SOSA & -.8920002 & .7924851 & -1.13 & 0.262 & -.8615751 & .7434952 & -1.16 & 0.247 \\
\hline
\end{tabular}




\begin{tabular}{lllllllll}
\hline EVSA & .3952577 & 1.36757 & 0.29 & 0.773 & .4695208 & 1.097511 & 0.43 & 0.669 \\
\hline GOSA & .2965334 & 1.13107 & 0.26 & 0.794 & .3782625 & .9146905 & 0.41 & 0.679 \\
\hline Prob > F & $0.0000^{*}$ & & \multicolumn{7}{c}{$0.03533^{*}$} \\
\hline Rho & 67.30 & & \multicolumn{7}{c}{67.174} & & \\
\hline
\end{tabular}

Significant @ 5\%*, Source: Author`s computation (2020)

Table 3. Hausman Test

\begin{tabular}{ll}
\hline Summary & Prob>chi $^{2}$ \\
\hline Cross section random & 0.7542 \\
\hline
\end{tabular}

Source: Author`s computation (2020)

Hausman test was used to identify the relative choice between fixed and random effect model. The Hausman test in Table 3 indicates that random effect is more appropriate and empirical discussion should be based on it since Prob>chi2 (0.7542) is higher than 0.05 .

From the random effect in Table 2, Social Sustainability Accounting (SOSA) shows negative and insignificant effect on Change in Turnover with the coefficient values of -0.8615751 and Prob. (t) of 0.247 while Environmental Sustainability Accounting (EVSA) and Governance Sustainability Accounting (GOSA) have an insignificant positive effect on Change in Turnover with coefficient values of 0.46952 and 0.37826 with Prob.(t) of 0.669 and 0.679 respectively. The Rho of $67 \%$ shows that the explanatory variables are responsible for about $67 \%$ variation in changes in turnover while other factors are responsible for about $33 \%$ variation in it. The Prob.(F-stat) of $0.03533<0.05$ explains that the explanatory variable has a joint significant effect on change in turnover. Thus, sustainability accounting exerts statistical significant effect on competitive advantage. Therefore, when firms provide stakeholders information regarding sustainability activities, firms will be portrayed as responsible entities among their peers. Thus investors and other stakeholders will be more attracted to the firm. Therefore, the null hypothesis is rejected. The findings are in line with the result of Pawel (2016), and Zhao, Meng, He and Gu (2019) which postulate significant positive effect of CSR on competitive advantage directly and indirectly as against the findings of Ahmad, Tawfiq, Ayman and Sakher (2019).

Hypothesis two: Sustainability accounting exerts no significant effect on market share of quoted companies in Nigeria.

To present an efficient result, both fixed and random effect models are estimated. The results are stated below:

Table 4. Summary of fixed effect and random effect result

\begin{tabular}{|c|c|c|c|c|c|c|c|c|}
\hline & \multicolumn{4}{|l|}{ Fixed Effect } & \multicolumn{4}{|c|}{ Random Effect } \\
\hline Variable & Coefficient & $\begin{array}{l}\text { Std. } \\
\text { Error }\end{array}$ & $\mathbf{t}$ & Prob. & Coefficient & $\begin{array}{l}\text { Std. } \\
\text { Error }\end{array}$ & $\mathbf{t}$ & Prob. \\
\hline $\mathbf{C}$ & 11.08877 & .1522415 & 72.84 & 0.000 & 11.01168 & .3038374 & 36.24 & 0.000 \\
\hline SOSA & -.2142661 & .32684 & -0.66 & 0.513 & -.1395144 & .3247809 & -0.43 & 0.668 \\
\hline
\end{tabular}




\begin{tabular}{lllllllll}
\hline EVSA & .7865397 & .6247432 & 1.26 & 0.209 & .7187341 & .584571 & 1.23 & 0.219 \\
\hline GOSA & -.0541342 & .5311382 & -0.10 & 0.919 & .0574694 & .4974015 & 0.12 & 0.908 \\
\hline Prob > F & $0.0000^{*}$ & & \multicolumn{7}{c}{$0.0113^{*}$} \\
\hline Rho & 88.769443 & & 86.98 & \\
\hline
\end{tabular}

Significant @ 5\%*, Source: Author`s computation (2020)

Table 5. Hausman Test

\begin{tabular}{ll}
\hline Test Summary & Prob>chi \\
\hline Cross section random & 0.0053 \\
\hline
\end{tabular}

Source: Author`s computation (2020)

Hausman test was carried out to identify the relative choice between fixed and random effect model. The Hausman test in Table 5 indicates that fixed effect is more appropriate and empirical discussion should be based on it since Prob>chi2 (0.0053) is less than 0.05.

Based on the choice of fixed effect by Hausman test in Table 5, Social Sustainability Accounting (SOSA) and Governance Sustainability Accounting (GOSA) show a negative and insignificant effect on Market Share (MS) with the coefficient values of -0.2142661 and -0.0541342 with Prob.(t) of 0.513 and 0.919 respectively. At the same time, Environmental Sustainability Accounting (EVSA) has an insignificant positive effect on Market Share (MS) with a coefficient value of 0.7865397 and Prob.(t) of 0.209. The implication of this is that sustainability accounting is an all encompassing variable which must be practiced together to be effective. This is shown by the result of Rho of $88 \%$ which shows that explanatory variables jointly responsible for about $88 \%$ variation in Market Share (MS) while other variables are responsible for about $12 \%$ variation in it. The Prob.(F-stat) of $0.0000<0.05$ explains that the explanatory variable has a significant joint effect on market share. The findings imply that when companies engage in, account and report their sustainability practices, it provides the channel through which investors - prospective and existing critically access the firm's ability to meet today's needs without limiting it ability of meeting stakeholder's future needs. Investors by their nature want today to be fair and tomorrow better, by ensuring steady returns and safety of their investments. Therefore investors will be attracted to firms that provide them with such information that will allow them take critical decisions as this especially when the figures are impressive. Investors may likely opt for such firm against firms which they don't have strong basis to base investment decisions. Thus, such firms will be provided with better consideration amidst its peers which will result in greater market share as the empirical findings in this study provides. Therefore, sustainability accounting has a significant effect on competitive advantage. Therefore, the null hypothesis is rejected.

\section{Discussion, Implication of Findings and Conclusion}

Based on the correlation and regression result of the tested hypotheses, sustainability accounting proxy by social sustainability, environmental and governance sustainability exerts significant effect on competitive advantage of quoted companies in Nigeria. These findings 


\section{Ml Macrothink}

International Journal of Accounting and Financial Reporting ISSN 2162-3082

imply that accounting for sustainability practices provides insight to various stakeholders by providing them with information that aid decision making processes that the regular financial statement do not provide, although another side to this is that it exposes firms which have poor sustainable practice and could provide a loop for negative insider information. However firms with good performance and efficient management will benefit much. As such extra information will provide limelight into some qualitative information to stakeholder which project good image of the firm, especially when such information meet the needs of stakeholders and as such build the reputation of firms over time. This will build vigor of corporate entities to mitigate against reputation risk, thus, building trust and improving relationship with various interest holders which and in turn, creating competitive advantage in the long run. Thus, the study recommends that the relevant regulatory authorities should encourage companies to comply, practice and report in line with GRI sustainability guideline. Also, the study recommends that corporate entities should endeavour to comply with the sustainability guidelines provided by GRI and NSE in practice and reporting as empirical evidence from this study shows that firms that comply with the GRI tend to have some level of competitive advantage provided by the positive signals from the qualitative information accounted and disclosed.

\section{Limitation of the Study}

The limitation encountered in this study was during data gathering. The researcher encountered challenges as regard availability of data for all the 167 quoted companies on the Nigerian Stock Exchange as at 31st December 2018 on sustainability reporting dimensions. To overcome this, the study adopted purposive sampling technique to select 28 sampled companies based on the criteria which includes: the company must have its sustainability report either as part of the annual report or separately and accessible on its website for the period of 2009 to 2018.

\section{References}

Adekunle, A. A., \& Asaolu, T. (2013). An empirical investigation of the financial reporting practices and banks' stability in Nigeria. Kuwait Chapter of Arabian Journal of Business and Management Review, 33(854), 1-24.

Ahmad, Y. A., Tawfiq, S. A., Ayman, A. A., \& Sakher, A. A. (2019). The effect of corporate social responsibility in achieving competitive advantage at Jordanian supply chain. International Journal of Supply Chain Management, 8(2), 531-540.

Akintoye, I. R., Jayeoba, O. O., Ajibade, A.T., Olayinka, I. M., \& Kwarbai, J. (2016). Value of accounting numbers and analysts' forecast errors . International Journal of Research and Methodology in Social Science, 2(3), 17-35.

Al-najjar, F. J. (2016). Social responsibility and its impact on competitive advantage (An applied study on Jordanian telecommunication companies). International Journal of Business and Social Science, 7(2), 114-125.

Aswini, K. D. (2013). Competitive advantage: Its importance and impact on design of strategy. International Journal of Application or Innovation in Engineering \& Management (IJAIEM), 2(12), 7-10. 


\section{Mll Macrothink}

International Journal of Accounting and Financial Reporting

ISSN 2162-3082 2020, Vol. 10, No. 2

Aziz, N. N. (2019). Organisational capabilities and competitive advantage: The moderating influence of managerial competencies. International Journal of Academic Research in Business and Social Sciences, 9(2), 782-794.

Ching, H. Y., Gerab, F., \& Toste, T. H. (2017). The quality of sustainability reports and corporate financial performance: Evidence from Brazilian listed companies. Journal of SAGE Open, 1-9.

Connelly, B. L., Certo, S. T., Ireland, R. D., \& Reutzel, C. R. (2011). Signaling theory: A review and assessment. Journal of Management, 37(39), 41-67.

Diab, S. M. (2014). Using the competitive dimensions to achieve competitive advantage: A study on Jordanian private hospitals. International Journal of Academic Research in Business and Social Sciences, 4(9), 138-150.

Dickinson, V., \& Sommers, G. A. (2012). Which competitive efforts lead to future abnormal economic rents? Using accounting ratios to assess competitive advantage. Journal of Business Finance and Accounting, 39(3-4), 360-398.

Emeka-Nwokeji, N. A., \& Osisioma, B. C. (2019). Sustainability disclosures and market value of firms in emerging economy: Evidence from Nigeria. European Journal of Accounting, Auditing and Finance Research, 7(3), 1-19.

Farole, T., Guilherme, R. J., \& Wagle, S. (2010). Analyzing trade competitiveness: A diagnostics approach, Policy Research Working, Paper 5329, 2010, The World Bank, Poverty Reduction and Economic Management Network, International Trade Department.

Global Repoorting Initiatives (GRI) G3. (2011). A new phase: The growth of sustainability reporting. 3.

Global Reporting Initiative (GRI) G4. (2015). Sustainability reporting guideline.

Isa, M. A. (2014). Sustainability reporting among Nigeria food and beverages firms. International Journal of Agriculture and Economic Development, 2(1), 3.

Ismail, A. I., Rose, R. C., Abdullah, H., \& Uli, J. (2010). The relationship between organisational competitive advantage and performance moderated by the age and size of firms. Asian Academy of Management Journal, 15(2), 157-173.

Kiel, J., Smith, R., \& Ubbels, B. (2014). The impact of transport investments on competitiveness. Transportation Research Procedia, 1, 77-88.

Kolk, A. (2004). A decade of sustainability reporting: Developments and significance. International Journal of Environment and Sustainable Development, 3(1), 51-64.

Kortelainen, S., \& Karkkainen, H. (2011). Dynamic model in understanding dynamics of competitiveness: System dynamics approach in mobile handset vendor business. Proceeding of Strategic Management Society (SMS), Annual International Conference, pp. 383-97.

Kozena, M., \& Chladek, T. (2012). Company competitiveness measurement depending on its size and field of activities. Journal of Procedia - Social and Behavioral Sciences, 58, 1085-1090. 


\section{Mll Macrothink}

International Journal of Accounting and Financial Reporting

ISSN 2162-3082

Loh, L., Thomas, T., \& Wang, Y. (2017). Sustainability reporting and firm value: Evidence from Singapore listed companies. Journal of Sustainability, 9(5), 1-12.

National Bureau of Statistics. (2019). Nigerian Gross Domestic Product (GDP) report quarter one 2019.

Nigerian Stock Exchange (NSE). (2016). Sustainability disclosure guideline. Retrieved $30^{\text {th }}$ May 2019 ,

from

http://www.nse.com.ng/regulationsite/IssuersRules/Sustainability\%20Disclosure\%20Guideli nes.pdf

Pawel, C. (2016). The concept of competitive advantages: Logic, sources and durability. Journal of Positive Management, 7(3), 57-70.

Persic, M., Jankovic, S., \& Krivacic, D. (2017). Sustainability accounting: Upgrading corporate social responsibility. Springer International Publishing, Switzerland.

Porter, M. E. (1985). Competitive advantage: Creating and sustaining superior performance (1st ed.). New York: The Free Press.

Rahman, N. A., \& Ramli, A. (2014). Entrepreneurship management, competitive advantage and firm performances in the craft industry: Concepts and framework. Journal of Procedia Social and Behavioral Sciences, 14(5), 129-137.

Rothaermel, F. T. (2008). Technological innovation: Generating economic results, advances in the study of entrepreneurship, innovation and economic growth (18th ed.). Elsevier Ltd.

Sachitra, V. (2015). Enhancing competitive advantage of Sri Lankan minor export crops. Journal of Global Economics, Management and Business Research, 4(4), 185-194.

Samad, S., Aziz, N. N. A., Jaidi, J., \& Masoud, Y. A. (2016). Influence of organizational capability on competitive advantage in small and medium enterprises (SMEs). International Business Management, 10(18), 4163-4171.

Smith, M. (2014). Issues of competitiveness and regional growth in relation to transport infrastructure investment: A literature review on assessment methodology. Retrieved $15^{\text {th }}$ December 2019, from http://www.i-ceu.eu/deliverables/I-C-EU_WP1_D1.1.pdf

Suprita, P. (2018). Emerging significance of sustainability accounting and reporting in india a conceptual study. International Journal of Accounting Research, 6(2), 180.

Taiwo, O. J., \& Owolabi, B. A. (2019). Environmental sustainability and corporate performance: The shareholders' perception. International Journal of Scientific and Research Publications, 9(10), 482-496.

Toit, J. P., Ortmann, G. F., \& Ramroop, S. (2010). Factors influencing the long-term competitiveness of commercial milk producers: Evidence from panel data in East Griqualand, South Africa. Agrekon, 49(1), 80-101.

Ucheagwu, C. J. (2019). Corporate sustainability practices and financial performance of firms listed on the Nigerian Stock Exchange (Unpublished Ph.D thesis). Babcock University, Ilishan-remo, Ogun State. 


\section{MInstitute ${ }^{\text {Macrothink }}$}

International Journal of Accounting and Financial Reporting

ISSN 2162-3082

Uchehara, F. O. (2019). Building a corporate competitiveness through corporate social responsibility drives. International Journal of Academic Research in Business and Social Sciences, 9(5), 531-541.

Urbanowska-Sojkin, E., Banaszyk, P., \& Witczak, H. (2007). Zarzadzanie strategiczne przedsiębiorstwem. Polskie Wydawnictwo Ekonomiczne, Warszawa.

Vilani, S. (2017). Review of competitive advantage measurements: reference on agribusiness sector. Journal of Scientific Research \& Reports, 12(6), 1-11.

Wang, C. L., Senaratne, C., \& Rafiq, M. (2015). Success traps, dynamic capabilities and firm performance. British Journal of Management, 26(1), 26-44.

Whetman, L. L. (2017). The impact of sustainability reporting on firm profitability. Undergraduate Economic Review, 14(1), 1-19.

Wijayanto, A., Suhadak, D. M., \& Nuzula, N. F. (2019). The effect of competitive advantage on financial performance and firm value: Evidence from Indonesian manufacturing companies. Russian Journal of Agricultural and Socio-economic Sciences, 1(85), 35-44.

Wikipedia (2019). List of largest manufacturing companies by revenue. Retrieved $4^{\text {th }}$ December 2019, from https://en.wikipedia.org/wiki/List_of_largest_manufacturing_com

Wirda, F. (2019). Competitive advantage: Mediation effect between entrepreneurial competency and business performance creative industries in West Sumatera-Indonesia. Academy of Entrepreneurship Journal, 25(1), 1-11.

Wirda, F., \& Rivai, H. A. (2019). Competitive advantage: Mediation effect between entrepreneurial competency and business performance creative industries in West Sumatera-Indonesia. Academy of Entrepreneurship Journal, 25(1), 1-11.

Yu, H., Kuo, L., \& Kao, M. (2017). The relationship between CSR disclosure and competitive advantage. Sustainability Accounting, Management and Policy Journal, 4(7), 120-130.

Zhao, Z., Meng, F., He, Y., \& Gu, Z. (2019). The influence of corporate social responsibility on competitive advantage with multiple mediations from social capital and dynamic capabilities. Sustainability, 11, 1-16.

\section{Copyright Disclaimer}

Copyright for this article is retained by the author(s), with first publication rights granted to the journal.

This is an open-access article distributed under the terms and conditions of the Creative Commons Attribution license (http://creativecommons.org/licenses/by/4.0/) 